AGRARIS: Journal of Agribusiness and Rural Develpoment Research

Vol. 4 No. 2 Juli-Desember 2018
Dyah Aring Hepiana Lestari, Fembriarti Erry Prasmatiwi, dan R. Hanung Ismono

Jurusan Agribisnis Fakultas Pertanian Universitas Lampung, Bandar Lampung

*)Email korespondensi: dyaharing@yahoo.com

\section{Analisis Perbandingan Biaya Transaksi, Pendapatan, dan Kesejahteraan Petani Kelapa Sawit Plasma dengan Swadaya di Kabupaten Tulang Bawang}

\section{Comparative Analysis of Transaction Costs, Revenue, and Welfare of Plasma and Self- supporting Oil Palm Farmers in Tulang Bawang Regency}

DOI: http://dx.doi.org/10.18196/agr.4266

\begin{abstract}
Transaction costs arise as a result of uncertainty in the transaction environment. Vertical integration of farmers in an institution will reduce uncertainty and will reduce transaction costs. Transaction costs will affect revenue and will ultimately affect the level of welfare. The objective of this research was to compare the transaction costs, revenue, and welfare between plasma oil palm farmers and self-supporting oil palm farmers. This research used a quantitative research approach with survey method. The research was conducted in Penawartama and Aji Baru sub-District, Tulang Bawang Regency. The research location was chosen purposively with the consideration of sub-district are the center of oil palm smallholdings. Data collection techniques were used household survey with simple random sampling. Sample size was 152 farmers consisting of 76 plasma farmers and 76 self-supporting farmers. The transaction costs paid by plasma farmers was smaller than those paid by self-
\end{abstract}

supporting farmers. Revenue per hectare of plasma smallholder was higher than the income of the self-supporting smallholder. Even though, oil palm farmers in Tulang Bawang Regency, both plasma and independent farmers were in the prosperous category.

Keywords: revenue, oil palm, transaction cost, welfare

\section{INTISAR}

Biaya transaksi muncul sebagai akibat ketidakpastian dalam lingkungan transaksi. Integrasi vertikal petani dalam sebuah kelembagaan akan mengurangi ketidakpastian yang dapat menurunkan biaya transaksi. Turunnya biaya transaksi akan meningkatkan pendapatan dan kesejahteraan petani. Penelitian ini bertujuan untuk membandingkan biaya transaksi, pendapatan, dan kesejahteraan petani kelapa sawit plasma dengan petani kelapa sawit swadaya di Kabupaten Tulang Bawang. Survei dilakukan di sentra perkebunan kelapa sawit rakyat, yaitu Kecamatan Penawartama dan Kecamatan Gedung Aji Baru. Data primer dikumpulkan dari 152 responden, terdiri dari 76 petani kelapa sawit plasma dan 76 petani kelapa sawit swadaya yang dipilih secara acak. Hasil penelitian membuktikan bahwa biaya transaksi yang dikeluarkan petani plasma lebih kecil dibandingkan dengan biaya transaksi yang dikeluarkan petani swadaya, sehingga petani plasma memperoleh pendapatan yang lebih besar dibandingkan petani swadaya. Namun demikian, baik petani kelapa sawit plasma maupun petani kelapa sawit swadaya termasuk dalam katagori sejahtera.

Kata kunci: biaya transaksi, kelapa sawit, kesejahteraan, pendapatan

\section{PENDAHULUAN}

Kelapa sawit merupakan salah satu komoditas perkebunan penting dan strategis, dengan kontribusi cukup signifikan terhadap perekonomian daerah maupun nasional (Samudera \&Daryanto, 2012). 
Perkebunan kelapa sawit berperan sebagai tulang punggung penerimaan devisa negara dan menjadi salah satu sektor perekonomian menyerap banyak tenaga kerja (Siradjuddin, 2015).

Indonesia merupakan produsen dan eksportir kelapa sawit terbesar dunia. Minyak sawit (CPO) Indonesia diklaim memiliki keunggulan komparatif di antara negara-negara penghasil $\mathrm{CPO}$ lain di dunia (Alatas, 2015). Karenanya, kelapa sawit memberikan sumbangan yang besar bagi perekonomian Indonesia, khususnya di Pulau Sumatra sebagai penghasil sawit terbesar. Selain membuka lapangan pekerjaan yang luas, kelapa sawit memberikan kontribusi yang besar terhadap PDRB daerah. Di Provinsi Lampung, industri minyak kelapa sawit merupakan leading sector dalam pembangunan ekonomi wilayah (Sari, Affandi, \& Abidin (2014). Dengan areal perkebunan terluas kedua setelah kopi robusta, kalapa sawit menjadi primadona sektor perkebunan di Provinsi Lampung (Muslih, Zakaria, \& Kasymir, 2013).

Perkebunan kelapa sawit rakyat di Provinsi Lampung melibatkan 995.792 petani, sekitar 34,43 persen dari keseluruhan petani pekebun yang ada di Provinsi Lampung (Dinas Perkebunan Provinsi Lampung, 2016). Perkebunan kelapa sawit rakyat di Provinsi Lampung lebih luas dibanding perkebunan kelapa sawit negara dan swasta. Pengembangan kelapa sawit rakyat di provinsi ini dimulai sejak adanya kebijakan PIR (Perkebunan Inti Rakyat) yang dikaitkan dengan program transmigrasi lokal. Dalam pola PIR, perkebunan besar bertindak sebagai inti yang berperan membangun perkebunan rakyat di sekitarnya atau petani dari luar daerah (transmigran) yang akan dijadikan sebagai plasma. Perkebunan inti dan plasma menganut sistem kerjasama yang saling menguntungkan dan berkelanjutan. Namun, sejak tahun 2000-an pola PIR berhenti, dan petani mengusahakan kelapa sawit secara swadaya.

Kabupaten Tulang Bawang menyumbang produksi kelapa sawit rakyat terbesar di Provinsi Lampung yaitu 45.773 ton; dengan luas area 19.155 ha, terdiri dari 15.583 ha tanaman menghasilkan dan sisanya belum menghasilkan (Dinas Perkebunan Provinsi Lampung, 2016). Pengembangan kelapa sawit rakyat dimulai pada tahun 1993, melalui pola intiplasma dengan transmigran lokal dari kabupaten lain di Provinsi Lampung sebagai petani plasma. Petani plasma bergabung dalam koperasi yang bertindak sebagai lembaga penghubung antara petani dengan perusahaan sebagai inti.
Dalam pola PIR, petani plasma hanya menyediakan lahan; sedangkan perusahaan inti bertanggungjawab dalam menyediakan bibit, pupuk, dan pestisida, serta memberikan bimbingan teknis penerapan teknologi budidaya. Sebagai konsekuensinya, petani harus menjual hasil kelapa sawitnya ke perusahaan inti. Dalam pola swadaya, petani menyediakan semua modal usahataninya dan mempunyai kebebasan untuk menjual hasil kelapa sawitnya kepada pedagang. Produktivitas kelapa sawit petani plasma pada umumnya lebih tinggi dibandingkan petani swadaya, karena petani plasma memperoleh jaminan ketersediaan modal dan bimbingan dari perusahaan. Dalam rantai pemasaran tandan buah segar (TBS), pabrik kelapa sawit (PKS) merupakan konsumen akhir, sehingga harga beli PKS menentukan harga pada pelaku pasar lainnya. Petani plasma sudah memiliki ikatan penjualan hasil dengan perusahaan, sehingga harga yang diterima petani plasma relatif lebih pasti. Harga ditentukan berdasarkan peraturan yang berlaku dan melibatkan pemerintah daerah (Dinas Perkebunan). Sementara itu, harga yang diterima petani swadaya sangat tergantung dari harga beli dari PKS dan pedagang pengumpul, yang di Provinsi Lampung sering disebut 'agen'.

Ketidakpastian yang dihadapi petani swadaya lebih tinggi dibanding petani plasma, karena petani plasma telah terintegrasi secara vertikal dalam koperasi yang bermitra dengan perusahaan inti. Petani swadaya diduga lebih banyak mengeluarkan biaya transaksi dibandingkan dengan petani plasma, yang muncul akibat dari adanya ketidakpastian dalam lingkungan transaksi (Huo, Ye, Zhao, Wei, \& Hua, 2018). Ketidakpastian tersebut meliputi opportunism satu pihak (Wang, Li, Ross, \& Craighead, 2013; Huo et al., 2018); ketidakpastian teknologi dan aliran informasi (Handley \& Benton, 2012; Lee, Yeung, \& Edwin Cheng, 2009); serta kondisi demand dan supply (Huo et al., 2018).

Keberadaan berbagai biaya transaksi akan meningkatkan biaya total yang dikeluarkan dalam usaha perkebunan kelapa sawit, yang akan menurunkan tingkat keuntungan (Kissell, 2008). Tingginya biaya transaksi yang dikeluarkan petani akan memperkecil pendapatan usahatani (Alfin Mohamad, Hadi Darwanto, \& Hartono, 2014). Biaya transaksi berpengaruh negatif dan signifikan terhadap keuntungan usahatani (Sultan \& Rachmina, 2016).

Jumlah biaya transaksi yang dikeluarkan petani kelapa sawit plasma dan swadaya akan 
mempengaruhi pendapatan yang diterima, dan pada akhirnya akan mempengaruhi tingkat kesejahteraannya. Penelitian ini bertujuan untuk membandingkan biaya transaksi, pendapatan, dan kesejahteraan petani kelapa sawit plasma dengan petani kelapa sawit swadaya di Kabupaten Tulang Bawang.

\section{METODE PENELITIAN}

Penelitian dilakukan di Kabupaten Tulang Bawang sebagai sentra produksi kelapa sawit di Provinsi Lampung dengan menggunakan metode survei. Sampel diambil dari Kecamatan Penawartama dan Kecamatan Gedung Aji Baru, dengan pertimbangan kecamatan tersebut memiliki perkebunan kelapa sawit terluas, jumlah petani rakyat terbanyak, dengan produktivitas tertinggi. Data dikumpulkan dari 152 responden, terdiri dari 76 petani kelapa sawit plasma dan 76 petani kelapa sawit swadaya, yang dipilih secara acak sederhana.

Analisis data dilakukan dengan metode deskriptif kuantitatif. Biaya transaksi mencakup biaya yang dikeluarkan petani untuk melakukan penelitian, mencari informasi, melakukan monitoring, dan melakukan partisipasi dalam satu tahun (Kusnadi, 2005). Analisis pendapatan petani kelapa sawit diperoleh dengan menghitung selisih antara penerimaan dengan biaya yang dikeluarkan dalam satu tahun (Suratiyah, 2015). Perbandingan biaya transaksi yang dikeluarkan dan pendapatan yang diterima, antara petani plasma dengan petani swadaya dianalisis menggunakan uji beda rata-rata (independent t-test).

Kesejahteraan petani diukur menggunakan indikator sosiometriks, yang mengklasifikasikan keluarga sejahtera berdasarkan 8 aspek, yaitu: ketahanan pangan, pendidikan, pelayanan kesehatan, perumahan, modal sosial, pemberdayaan, buta huruf, dan kerawanan dalam keluarga tersebut. Keluarga tergolong sebagai keluarga tidak sejahtera (miskin) apabila tidak dapat memenuhi sebagian besar dari delapan komponen kesejahteraan secara layak (Hartoyo \& Aniri, 2010). Pemenuhan setiap aspek kesejahteraan diukur menggunakan skala ordinal dengan pemberian skor dari 1(satu) untuk kondisi sangat memenuhi sampai 4 (empat) untuk kondisi sangat tidak memenuhi. Selanjutnya tingkat kesejahteraan keluarga diukur dengan menjumlahkan skor delapan aspek tersebut; dan dikatagorikan dalam tiga katagori, yakni: sejahtera (skor 8 -15), tidak sejahtera (skor 16 - 23), dan sangat tidak sejahtera (skor 24-32). Perbandingan kesejahteraan petani plasma dan swadaya dianalisis menggunakan uji beda Mann-Whitney.

\section{HASIL DAN PEMBAHASAN}

Baik petani kelapa sawit plasma maupun swadaya mayoritas berusia produktif, yaitu kurang dari 65 tahun dengan tingkat pendidikan bervariasi mulai dari lulusan SD hingga SMA. Mayoritas petani swadaya berpendidikan lulusan SMA, sedangkan mayoritas petani plasma berpendidkan lulusan SMP. Lebih dari separuh petani berpengalaman dalam mengusahakan kelapa sawit antara $14-27$ tahun, yaitu 57,90 persen untuk petani plasma dan 56,60 persen untuk petani swadaya.

Lahan petani plasma dan swadaya berstatus milik sendiri. Rata-rata lahan petani swadaya lebih luas (2,12 ha) dibandingkan lahan petani plasma (1,41 ha). Seluruh petani plasma memiliki tanaman kelapa sawit yang telah berumur antara 17 - 23 tahun, sedangkan petani swadaya mayoritas $(56,60$ persen) memiliki tanaman kelapa sawit yang masih berumur antara 10 - 16 tahun.

\section{BIAYA TRANSAKSI PETANI KELAPA SAWIT POLA PLASMA DAN SWADAYA}

Biaya transaksi yang dikeluarkan petani kelapa sawit terdiri dari biaya penelitian, biaya informasi, biaya monitoring, dan biaya partisipasi; yang masing-masing terdiri dari empat komponnen biaya, yakni biaya transportasi, biaya komunikasi, biaya administrasi, dan biaya konsumsi. Hal ini berbeda dengan biaya transaksi dalam penelitian Sultan dan Rachmina (2016) yang terdiri dari biaya negosiasi, biaya informasi, biaya koordinasi, biaya pelaksanaan, biaya monitoring, dan biaya risiko.

Biaya penelitian adalah biaya yang dikeluarkan petani untuk mengetahui berbagai pelayanan yang disediakan pedagang/koperasi. Biaya informasi adalah biaya yang dikeluarkan petani untuk 
mengetahui kualitas dan harga tandan buah segar. Biaya monitoring adalah biaya yang dikeluarkan petani untuk melakukan pengawasan kontrak dengan pedagang/koperasi. Biaya partisipasi meliputi biaya untuk menghadiri rapat anggota tahunan (RAT), membayar simpanan wajib, dan memanfaatkan pelayanan koperasi.

Biaya informasi dikeluarkan oleh petani plasma maupun petani swadaya, sedangkan biaya penelitian dan monitoring hanya dikeluarkan petani swadaya. Biaya partisipasi hanya dikeluarkan oleh petani plasma yang bergabung dalam koperasi dan berkewajiban berpartisipasi dalam kegiatan koperasi. Sementara itu, petani swadaya tidak bergabung dalam koperasi atau bekerjasama dengan lembaga lain, sehingga tidak mengeluarkan biaya partisipasi dalam mengusahakan kebunnya. Rincian biaya transaksi yang dikeluarkan petani plasma dan petani swadaya disajikan pada Tabel 1.

\section{TABEL 1. BIAYA TRANSAKSI PETANI PLASMA DAN PETANI SWADAYA SELAMA SATU TAHUN DIKABUPATEN TULANG BAWANG}

\begin{tabular}{|c|c|c|c|c|c|}
\hline \multirow[t]{2}{*}{ Biaya Transaksi } & \multirow[t]{2}{*}{ Uraian } & \multicolumn{2}{|c|}{ Plasma } & \multicolumn{2}{|c|}{ Swadaya } \\
\hline & & (Rp) & $(\%)$ & (Rp) & $(\%)$ \\
\hline \multirow{3}{*}{ Biaya Penelitian } & B.Transportasi & 0,00 & 0,00 & 94.263 & 43,39 \\
\hline & B. Komunikasi & 0,00 & 0,00 & 26 & 0,01 \\
\hline & B. Konsumsi & 0,00 & 0,00 & 60.355 & 27,78 \\
\hline \multirow{2}{*}{ Biaya Informasi } & B.Transportasi & 14.842 & 22,22 & 6.947 & 3,20 \\
\hline & B. Komunikasi & 16.579 & 24,82 & 31.938 & 14,70 \\
\hline $\begin{array}{l}\text { Biaya } \\
\text { Monitoring }\end{array}$ & B. Transportasi & 0,00 & 0,00 & 28.342 & 13,05 \\
\hline \multirow{2}{*}{$\begin{array}{l}\text { Biaya } \\
\text { Partisipasi: RAT }\end{array}$} & B. Transportasi & 1.342 & 2,01 & 0,00 & 0,00 \\
\hline & B. Komunikasi & 349 & 0,52 & 0,00 & 0,00 \\
\hline \multirow{3}{*}{$\begin{array}{l}\text { Biaya } \\
\text { Partisipasi: } \\
\text { Memanfaatkan } \\
\text { Pelayanan }\end{array}$} & B. Transportasi & 2.855 & 4,27 & 0,00 & 0,00 \\
\hline & B. Komunikasi & 237 & 0,35 & 0,00 & 0,00 \\
\hline & B. Administrasi & 30.592 & 45,80 & 0,00 & 0,00 \\
\hline \multicolumn{2}{|c|}{ Biaya transaksi total } & 66.796 & 100.00 & 217 & 100,00 \\
\hline
\end{tabular}

Tabel 1 menunjukkan bahwa biaya penelitian merupakan biaya transaksi terbesar yang harus dikeluarkan petani swadaya, yakni Rp 94 ribu untuk biaya transportasi dan $\mathrm{Rp} 60$ ribu untuk konsumsi.
Sementara petani plasma tidak perlu mengeluarkan biaya transaksi untuk kegiatan penelitian. Petani plasma tergabung dalam koperasi yang memiliki kegiatan yang pasti yakni melayani kebutuhan petani plasma anggotanya. Walaupun demikian, petani plasma maupun petani swadaya sama-sama membutuhkan informasi yang bisa diperoleh dengan cara berkomunikasi melalui handphone. Oleh karena itu biaya informasi yang dikeluarkan petani plasma dan petani swadaya sebagian besar berupa biaya komunikasi, masing-masing sebesar Rp 16 ribu dan Rp 31 ribu. Petani plasma tidak mengeluarkan biaya monitoring karena berbagai kegiatan dilakukan melalui koperasi, sedangkan petani swadaya mengeluarkan biaya monitoring berupa biaya transportasi sebesar Rp 28 ribu.

Sebagai konsekuensi tergabung dalam koperasi, petani plasma harus mengeluarkan biaya partisipasi, yang tidak perlu dikeluarkan petani swadaya. Namun, biaya partisipasi yang dikeluarkan petani plasma, sebagian besar untuk biaya administrasi (Rp 30 ribu), jauh lebih kecil dari biaya yang dikeluarkan petani swadaya untuk kegiatan penelitian. Oleh karena itu, biaya transaksi petani plasma jauh lebih kecil (kurang dari biaya $\mathrm{Rp} \quad 67$ ribu) dibandingkan biaya transaksi yang harus dikeluarkan petani swadaya (sekitar Rp 217 ribu). Petani plasma mengeluarkan biaya transaksi untuk biaya informasi dan partisipasi dengan proporsi yang seimbang. Sementara itu, petani swadaya mengeluarkan biaya transaksi untuk biaya penelitian, biaya informasi dan biaya monitoring, yang didominasi biaya penelitian (71,18 persen). Hal ini berbeda dengan biaya transaksi pada komoditas kedelai di Kabupaten Lamongan yang didominasi biaya negosiasi, yaitu sebesar 60,30 persen (Sultan dan Rachmina, 2016).

Biaya transaksi yang dikeluarkan petani swadaya lebih besar dibandingkan biaya transaksi yang dikeluarkan petani plasma. Hal ini disebabkan, petani swadaya mengusahakan kebunnya secara mandiri mulai dari kepemilikan lahan, permodalan, pengolahan lahan, sampai panen. Berbeda halnya dengan petani plasma yang pengelolaan kebunnya dilakukan oleh koperasi, sehingga biaya transaksi yang dikeluarkan dapat ditekan. Hasil uji beda 
mendapatkan nilai $\mathrm{t}$ hitung sebesar $-8,108$ yang membuktikan lebih rendahnya biaya transaksi yang dikeluarkan petani plasma dibandingkan dengan biaya transaksi yang dikeluarkan petani swadaya, pada tingkat kepercayaan 99 persen.

\section{PENDAPATAN PETANI KELAPA SAWIT POLA PLASMA DAN SWADAYA}

Petani plasma merupakan petani yang bekerjasama dengan perusahaan dengan hak dan kewajiban yang telah disepakati oleh kedua belah pihak. Lahan kebun petani dikelola oleh perusahaan dan hasil dari usaha kebun tersebut dibagi sesuai dengan perjanjian. Koperasi bertindak sebagai penghubung atau perantara dalam pembayaran hasil kebun kepada petani plasma.

Petani plasma memiliki lahan dengan luas rata-rata 1,41 hektare dan rata-rata umur tanaman kelapa sawit 21,92 tahun. Petani plasma tidak mengelola sendiri kebun kelapa sawitnya, sehingga pada saat panen petani tidak mengetahui dengan tepat berapa produksi yang diperoleh dan harga jual yang diterima. Setiap bulan petani mendapatkan hasil bersih atau pendapatan yang dibagikan lewat koperasi ke masing-masing kelompok taninya, semua anggota kelompok tani memperoleh pendapatan yang sama. Setelah dikurangi dengan biaya transaksi, petani plasma memperoleh pendapatan dari kebun kelapa sawitnya sekitar Rp30,4 juta per 1,41 hektar per tahun.

Petani swadaya merupakan petani yang memiliki kebun kelapa sawit yang diusahakan secara mandiri mulai dari kepemilikan lahan, permodalan, pengelolaan kebun hingga panen, bahkan untuk penjualan hasil panennya. Keterbatasan modal dan tidak adanya bimbingan teknis menyebabkan produksi kelapa sawit petani swadaya cenderung lebih rendah dibandingkan petani plasma.

Salah satu faktor yang mempengaruhi produksi tandan buah segar kelapa sawit adalah pupuk. Pemupukan harus memperhatikan umur tanaman kelapa sawit. Pemupukan kelapa sawit yang benar adalah pemupukan dengan menggunakan pupuk tunggal yaitu Rock Phospate untuk memenuhi kebutuhan unsur P, Kieserit untuk memenuhi kebutuhan unsur $\mathrm{Mg}$, Urea untuk memenuhi kebutuhan unsur N, serta MOP (Muriate of Potash) untuk memenuhi kebutuhan unsur K (Panggabean \& Purwono, 2017).

Rata-rata penggunaan pupuk Urea oleh petani swadaya sebesar $2,70 \mathrm{~kg} /$ pohon/tahun, sedangkan anjurannya hanya $2,50 \mathrm{~kg} /$ pohon/tahun. Sementara itu, penggunaan pupuk $\mathrm{KCl}$ kurang dari yang direkomendasikan yaitu 2,00 $\mathrm{kg} /$ pohon/tahun. Pupuk kandang digunakan sebanyak 24,93 $\mathrm{kg} /$ pohon/tahun. Obat-obatan yang digunakan petani swadaya untuk pengendalian organisme penggangu tanaman antara lain regent, gramoxone, redox, dan round up. Petani swadaya menggunakan tenaga kerja luar keluarga pada kegiatan pemanenan dengan curahan tenaga kerja sebesar 30,90 HOK per 2,12 hektare per tahun; sedangkan tenaga kerja dalam keluarga yang digunakan hanya sebesar 13,16 HOK per 2,12 hektare per tahun.

Produksi TBS kelapa sawit pada bulan Agustus 2016 hingga Juli 2017 mengalami fluktuasi yang cenderung menurun (Gambar 1). Produksi tertinggi terjadi pada bulan November 2016, sebesar $2.149 \mathrm{~kg}$ per hektare; sedangkan produksi terendah terjadi pada bulan Mei 2017 hanya sebesar 811 kg per hektare. Harga jual TBS kelapa sawit pada bulan Agustus 2016 hingga Juli 2017 juga berfluktuasi, tetapi tidak terlalu besar atau relatif stabil. Harga jual tertinggi terjadi pada bulan Maret 2017 sebesar $\mathrm{Rp} 1.301 / \mathrm{kg}$ dan harga jual terendah terjadi pada bulan Juni 2017 sebesar Rp915/kg.

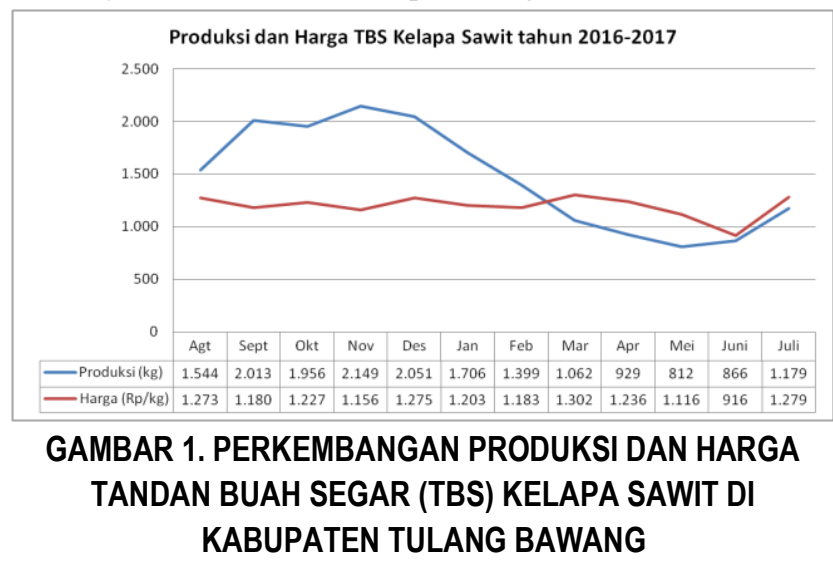

Pendapatan usaha kebun kelapa sawit petani swadaya adalah selisih dari penerimaan dengan biaya produksi dan biaya transaksi (Tabel 20). Biaya 
produksi yang dikeluarkan dirinci atas biaya tunai dan biaya diperhitungkan. Dengan penerimaan sekitar Rp45 juta, dalam satu tahun petani swadaya menikmati pendapatan atas biaya tunai sebesar $\mathrm{Rp}$ 35,8 juta atau pendapatan atas biaya total sebesar Rp34.4 juta untuk luasan 2,12 hektar. Perbandingan penerimaan dengan biaya, baik atas tunai maupun atas biaya total lebih besar dari satu (R/C $>1)$, menunjukkan usaha kelapa sawit petani swadaya menguntungkan.

TABEL 2. RATA-RATA PENERIMAAN, BIAYA, DAN PENDAPATAN USAHA KEBUN KELAPA SAWIT SWADAYA SELAMA SATU TAHUN DI KABUPATEN TULANG BAWANG

\begin{tabular}{|c|c|c|c|c|}
\hline \multirow[b]{2}{*}{ Uraian } & \multicolumn{4}{|c|}{ Usahatani per 2,12 ha } \\
\hline & Jumlah & Satuan & $\begin{array}{l}\text { Harga } \\
(\mathrm{Rp})\end{array}$ & Nilai (Rp) \\
\hline \multicolumn{2}{|c|}{ Total Penerimaan 1 tahun } & & & $45.128 .431,2$ \\
\hline \multicolumn{5}{|c|}{ I. Biaya Produksi } \\
\hline \multicolumn{5}{|l|}{ 1. Biaya Tunai } \\
\hline Pupuk Urea & 768,14 & $\mathrm{Kg}$ & $2.200,00$ & $1.689 .918,42$ \\
\hline Pupuk Phonska & 226,05 & $\mathrm{Kg}$ & $3.300,00$ & $745.973,68$ \\
\hline Pupuk KCl & 51,97 & $\mathrm{Kg}$ & $6.000,00$ & $311.842,11$ \\
\hline Pupuk Kandang & $7.105,46$ & $\mathrm{Kg}$ & 498,00 & $3.538 .519,34$ \\
\hline Obat-obatan & & $\mathrm{Rp}$ & & $172.481,58$ \\
\hline TK Luar Keluarga & 30,90 & HOK & $79.381,72$ & $2.452 .738,49$ \\
\hline PBB & & $\mathrm{Rp}$ & & $142.505,59$ \\
\hline Total Biaya Tunai & & & & $9.053 .979,21$ \\
\hline \multicolumn{5}{|c|}{ 2. Biaya Diperhitungkan } \\
\hline TK dalam Keluarga & 13,16 & HOK & $79.543,75$ & $1.046 .628,29$ \\
\hline Penyusutan Alat & & $\mathrm{Rp}$ & & $437.242,01$ \\
\hline \multirow{2}{*}{\multicolumn{2}{|c|}{$\begin{array}{l}\text { Total Biaya Diperhitungkan } \\
\text { 3. Total Biaya } \\
\text { Produksi }\end{array}$}} & & & $1.483 .870,30$ \\
\hline & & & & $10.537 .849,5$ \\
\hline II. Biaya transaksi & & $\mathrm{Rp}$ & & $217.250,00$ \\
\hline \multicolumn{5}{|l|}{ Pendapatan } \\
\hline \multicolumn{2}{|c|}{ 1. Pendapatan atas Biaya Tunai } & & & $35.857 .202,0$ \\
\hline \multicolumn{2}{|c|}{ 2. Pendapatan atas Biaya Total } & & & $34.373 .331,7$ \\
\hline \multicolumn{2}{|l|}{$\mathrm{R} / \mathrm{C}$ atas biaya tunai } & & & 4,87 \\
\hline $\mathrm{R} / \mathrm{C}$ atas biaya total & & & & 4,20 \\
\hline
\end{tabular}

Rata-rata pendapatan usaha kelapa petani plasma (Rp21,6 juta/Ha/tahun) lebih tinggi dari pada petani swadaya (Rp16,9 juta/Ha/tahun). Hasil uji beda dengan nilai thitung sebesar 5,400 membuktikan bahwa secara statistik pendapatan petani plasma lebih tinggi dari pada pendapatan petani swadaya pada tingkat kepercayaan 99 persen.
Hal ini disebabkan kebun kelapa sawit petani plasma dikelola koperasi dengan standar pengelolaan yang lebih baik. Integrasi petani plasma dengan perusahaan inti, melalui koperasi mengurangi ketidakpastian, sehingga fluktuasi produksi dan harga TBS, serta besarnya biaya transaksi yang harus dikeluarkan dapat ditekan. Sementara itu, petani swadaya mengelola kebun kelapa sawitnya secara mandiri sehingga rawan terhadap ketidakpastian, baik fluktuasi produksi maupun harga TBS, serta memerlukan biaya transaksi yang lebih besar.

Hasil penelitian ini sama dengan hasil penelitian sebelumnya yang menemukan bahwa pendapatan usaha kebun kelapa sawit petani plasma lebih tinggi dari petani swadaya (Lestari, Hutabarat, \& Dewi, 2015). Produktivitas kebun kelapa sawit petani plasma yang lebih tinggi merupakan faktor yang sangat berpengaruh terhadap tingkat pendapatan. Disamping itu, petani plasma pada umumnya mendapatkan harga TBS yang lebih tinggi karena rendemen minyak sawit yang dihasilkan lebih baik dari petani swadaya.

\section{KESEJAHTERAAN PETANI KELAPA SAWIT POLA PLASMA DAN SWADAYA}

Tingkat kesejahteraan dianalisis dari kemampuan petani memenuhi delapan aspek sebagai indikator kesejahteraan, yang masing-masing diberi skor dengan kisaran 1-4. Skor 1 diberikan untuk kemampuan pemenuhan indikator kesejahteraan sangat tinggi, sedangkan skor 4 diberikan untuk kemampauan pemenuhan indikator sangat rendah. Proporsi petani (\%) berdasarkan skor indikator kesejahteraan sebagaimana ditampilkan pada Tabel 3, menunjukkan tidak terdapat perbedaan kesejahteraan antara petani plasma dengan petani swadaya.

Dari delapan indikator kesejahteraan, tidak ada indikator yang mendapat skor 4. Hal ini menunjukkan tidak ada petani yang pemenuhan indikator kesejahteraannya sangat rendah. Indikator ketahanan pangan, pendidikan, peralatan rumah tangga, kemampuan baca tulis, dan kerawanan hanya mendapat skor 1 dan 2, artinya pemenuhan indikator kesejahteran untuk aspek-aspek tersebut sudah tinggi 
atau sangat tinggi. Sementara itu, untuk aspek pelayanan kesehatan, modal sosial, dan pemberdayaan diperoleh variasi skor 1, 2 dan 3; artinya pemenuhan indikator kesejahteraan untuk aspek-aspek tersebut ada yang masih rendah.

TABEL 3. PERBEDAAN PROPORSI (\%) PETANI PLASMA DAN PETANI SWADAYA BERDASARKAN DELAPAN ASPEK INDIKATOR KESEJAHTERAAN

\begin{tabular}{|c|c|c|c|c|}
\hline Indikator & Skor & Keterangan Indikator & $\begin{array}{c}\text { Plasma } \\
(\%)\end{array}$ & $\begin{array}{l}\text { Swaday } \\
\text { a }(\%)\end{array}$ \\
\hline \multirow{3}{*}{$\begin{array}{l}\text { Ketahanan } \\
\text { Pangan }\end{array}$} & 1 & Kecukupan pangan dan & 57,90 & 88,20 \\
\hline & & sesuai yang diinginkan & & \\
\hline & 2 & $\begin{array}{l}\text { Kecukupan pangan dan } \\
\text { jenisnya tidak sesuai } \\
\text { yang diinginkan }\end{array}$ & 42,10 & 11,80 \\
\hline \multirow[t]{2}{*}{ Pendidikan } & 1 & $\begin{array}{l}\text { Pendidikan hingga } \\
\text { perguruan tinggi }\end{array}$ & 72,40 & 44,70 \\
\hline & 2 & $\begin{array}{l}\text { Pendidikan pada level } \\
\text { menengah }\end{array}$ & 27,60 & 55,30 \\
\hline \multirow[t]{3}{*}{$\begin{array}{l}\text { Pelayanan } \\
\text { Kesehatan }\end{array}$} & 1 & $\begin{array}{l}\text { Selalu memperoleh } \\
\text { obat-obatan dan } \\
\text { pelayanan kesehatan }\end{array}$ & 46,10 & 53,90 \\
\hline & 2 & $\begin{array}{l}\text { Biasanya mampu } \\
\text { memperoleh obat- } \\
\text { obatan dan pelayanan } \\
\text { kesehatan }\end{array}$ & 52,60 & 46,10 \\
\hline & 3 & $\begin{array}{l}\text { Terkadang tidak mampu } \\
\text { memperoleh obat- } \\
\text { obatan dan pelayanan } \\
\text { kesehatan }\end{array}$ & 1,30 & 0,00 \\
\hline \multirow[t]{2}{*}{$\begin{array}{l}\text { Peralatan } \\
\text { Rumah } \\
\text { Tangga }\end{array}$} & 1 & $\begin{array}{l}\text { Mempunyai seluruh } \\
\text { perlengkapan rumah } \\
\text { tangga moderen }\end{array}$ & 96,10 & 92,10 \\
\hline & 2 & $\begin{array}{l}\text { Keluarga mempunyai } 3 \\
\text { dari } 4 \text { perlengkapan }\end{array}$ & 3,90 & 7,90 \\
\hline \multirow[t]{3}{*}{$\begin{array}{l}\text { Modal } \\
\text { Sosial }\end{array}$} & 1 & $\begin{array}{l}\text { Rumah tangga selalu } \\
\text { terlibat dalam aktivitas } \\
\text { masyarakat }\end{array}$ & 42,10 & 35,50 \\
\hline & 2 & $\begin{array}{l}\text { Rumah tangga } \\
\text { terkadang terlibat dalam } \\
\text { aktivitas masyarakat }\end{array}$ & 42,10 & 57,90 \\
\hline & 3 & $\begin{array}{l}\text { Rumah tangga jarang } \\
\text { terlibat dalam aktivitas } \\
\text { masyarakat }\end{array}$ & 15,80 & 6,60 \\
\hline \multirow[t]{3}{*}{$\begin{array}{l}\text { Pemberda } \\
\text { yaan }\end{array}$} & 1 & $\begin{array}{l}\text { Klien selalu merasa } \\
\text { dihormati }\end{array}$ & 35,50 & 11,80 \\
\hline & 2 & $\begin{array}{l}\text { Klien terkadang merasa } \\
\text { dihormati }\end{array}$ & 64,50 & 85,50 \\
\hline & 3 & $\begin{array}{l}\text { Klien jarang merasa } \\
\text { dihormati }\end{array}$ & 0,00 & 2,60 \\
\hline \multirow[t]{2}{*}{$\begin{array}{l}\text { Kemampu } \\
\text { an Baca } \\
\text { Tulis }\end{array}$} & 1 & $\begin{array}{l}\text { Klien dapat membaca, } \\
\text { menulis, dan berhitung } \\
\text { dasar }\end{array}$ & 98,70 & 100,00 \\
\hline & 2 & $\begin{array}{l}\text { Klien dapat melakukan } 2 \\
\text { dari } 3 \text { kemampuan }\end{array}$ & 1,30 & 0,00 \\
\hline \multirow[t]{2}{*}{$\begin{array}{l}\text { Kerawana } \\
n\end{array}$} & 1 & $\begin{array}{l}\text { Tidak mempunyai } \\
\text { kerawanan (balita, } \\
\text { lansia, anggota keluarga } \\
\text { berpenyakit kronis) }\end{array}$ & 98,70 & 100,00 \\
\hline & 2 & $\begin{array}{l}\text { Keluarga mempunyai } 1 \\
\text { dari } 3 \text { kerawanan }\end{array}$ & 1,30 & 0,00 \\
\hline
\end{tabular}

Aspek ketahanan pangan keluarga dilihat berdasarkan kemampuan keluarga untuk memenuhi kebutuhan pangan dengan bahan pangan sesuai keinginan. Sebagian besar petani, 58 persen petani plasma dan $88 \%$ petani swadaya, merasa bahwa keluarga mereka selalu mempunyai bahan pangan yang cukup dan mampu memenuhi jenis makanan yang diinginkan. Sementara sebagian lainnya merasa bahwa keluarga mereka selalu mempunyai bahan pangan yang cukup, namun tidak selalu mampu memenuhi jenis makanan yang diinginkan. Lebih tingginya proporsi petani swadaya yang mampu memenuhi kebutuhan pangan dengan jenis makanan sesuai keinginan mengindikasikan lebih tingginya kesejahteraan petani swadaya dilihat dari aspek ketahanan pangan.

Aspek pendidikan dinilai berdasarkan kemampuan keluarga petani untuk mendukung anggota keluarganya mencapai tingkat pendidikan tertinggi. Sebagian besar petani plasma (72 persen) merasa mampu untuk mendukung pendidikan anakanaknya hingga jenjang universitas, sedangkan sebagian besar petani swadaya (55 persen) hanya mampu mendukung pendidikan anak-anaknya hingga jenjang sekolah menengah. Hal ini menunjukkan lebih tingginya kesejahteraan petani plasma dilihat dari aspek pendidikan

Aspek pelayanan kesehatan dinilai berdasarkan kemampuan petani untuk memperoleh obat-obatan dan pelayanan kesehatan yang dibutuhkan. Proporsi petani swadaya yang selalu mampu memperoleh obat-obatan dan pelayanan kesehatan yang dibutuhkan lebih besar (54 persen) dibandingkan petani plasma (46 persen). Bahkan masih terdapat petani plasma (1 persen) yang kadang tidak mampu memenuhi kebutuhan obat-obatan dan pelayanan kesehatan. Hal ini menunjukkan kesejahteraan petani swadaya lebih tinggi dari petani plasma dilihat dari aspek pelayanan kesehatan.

Aspek peralatan rumah tangga dinilai berdasarkan apakah petani mempunyai perlengkapan moderen termasuk pompa air, listrik, septic-tank, dan telepon. Hampir keseluruhan petani, 96 persen petani plasma dan 92 persen swadaya, memiliki semua perlengkapan modern; sedangkan sebagian lainnya 
memiliki 3 dari 4 perlengkapan moderen yang seharusnya dimiliki. Hal ini menunjukkan sudah tingginya kesejahteraan petani, baik plasma maupun swadaya, dilihat dari aspek kepemilikan perlengkapan rumahtangga.

Aspek modal sosial dilihat berdasarkan keterlibatan petani dalam kegiatan masyarakat. Petani plasma yang selalu terlibat dalam kegiatan masyarakat lebih banyak (42 persen) dari pada petani swadaya (35 persen). Demikian pula petani plasma yang jarang terlibat dalam kegiatan masyarakat (16 persen) lebih banyak dari pada petani swadaya (7 persen). Hal ini menunjukkan tidak terdapat perbedaan tingkat kesejahteraan petani dilihat dari aspek modal sosial.

Aspek pemberdayaan dinilai dari sejauhmana petani merasa dihormati oleh masyarakat. lam menentukan tingkat kesejahteraan petani. Sebagian besar petani, baik petani plasma (65 persen) maupun petani swadaya (85 persen), terkadang merasa dihormati di masyarakat. Petani plasma yang merasa selalu dihormati (36 persen) lebih banyak dari pada petani swadaya (12 persen). Hal ini menunjukkan kesejahteraan petani plasma lebih tinggi dibandingkan petani swadaya dilihat dari aspek pemberdayaan. Rendahnya kesejahteraan petani swadaya dilihat dari aspek pemberdayaan ditunjukkan dari terdapatnya petani swadaya jarang merasa dihormati (3 persen).

Dilihat dari aspek kemampuan baca tulis dan aspek kerawanan, hampir seluruh petani plasma (99 persen) dan seluruh petani swadaya (100 persen) memiliki kemampuan membaca, menulis, dan berhitung dasar; dan tidak memiliki kerawanan dalam keluarga, yaitu tidak ada balita, lansia dan anggota keluarga yang mengidap penyakit kronis. Artinya, kesejahteraan petani dilihat dari kedua aspek ini termasuk dalam katagori sangat tinggi.

Skor total semua aspek kesejahteraan yang diperoleh petani plasma maupun swadaya berkisar antara 8-14, dengan modus 10 untuk petani plasma dan 11 untuk petani swadaya. Dengan demikian, seluruh petani kelapa sawit yang dijadikan responden termasuk dalam katagori sejahtera (Tabel 4).
TABEL 4. SEBARAN PETANI PLASMA DAN SWADAYA BERDASARKAN TINGKAT KESEJAHTERAAN

\begin{tabular}{rlrrrrr} 
& & \multicolumn{2}{c}{ Plasma } & \multicolumn{2}{c}{ Swadaya } \\
\cline { 3 - 6 } Total Skor/Kategori & $\begin{array}{l}\text { Jumlah } \\
\text { (orang) }\end{array}$ & $\%$ & $\begin{array}{r}\text { Jumlah } \\
\text { (orang) }\end{array}$ & $\%$ \\
\hline $8-15$ & (Sejahtera) & 76 & 100,00 & 76 & 100,00 \\
$16-23$ & (Tidak sejahtera) & 0 & 0,00 & 0 & 0,00 \\
$24-32$ & (Sangat tidak sejahtera) & 0 & 0,00 & 0 & 0,00 \\
\hline
\end{tabular}

Dari Tabel 4 dapat dilihat bahwa seluruh petani kelapa sawit baik plasma maupun swadaya tergolong dalam kategori sejahtera karena termasuk dalam interval total skor antara 8 hingga 15 . Hal ini sesuai dengan penelitian sebelumnya yang menyatakan usahatani kelapa sawit dapat meningkatan kesejahteraan petani di pedesaan (Syahza, 2013). Hasil uji beda Mann Whitney yang menghasilkan Z-hitung $=-0,583$ mengindikasikan bahwa tingkat kesejahteraan petani plasma tidak berbeda nyata dengan tingkat kesejahteraan petani swadaya.

\section{KESIMPULAN}

Integrasi petani plasma dengan perusahaan inti melalui koperasi menyebabkan biaya transaksi yang dikeluarkan petani plasma jauh lebih kecil dibandingkan biaya transaksi yang dikeluarkan petani swadaya, masing-masing 67 ribu dan 127 ribu rupiah. Usaha kebun kelapa sawit rakyat di Kabupaten Tulang Bawang yang dilakukan oleh petani plasma maupun petani swadaya sama-sama menguntungkan, tetapi pendapatan petani plasma per hektar per tahun lebih tinggi 4-5 juta rupiah dibanding pendapatan petani swadaya. Namun demikian, lebih luasnya kebun yang dikelola petani swadaya (2,12 hektar) dibandingkan petani plasma (1,41 hektar), menyebabkan pendapatan petani swadaya per tahun sedikit lebih tinggi dari petani plasma. Konsekuensinya, baik petani plasma maupun petani swadaya sama-sama termasuk dalam katagori sejahtera.

Perbedaan pendapatan usaha kebun kelapa sawit yang cukup tinggi antara petani plasma dan petani swadaya menunjukkan pentingnya kelembagaan bagi petani kelapa sawit. Untuk mewujudkannya, diperlukan upaya-upaya dari pihakpihak terkait baik pemerintah, swasta, maupun 
institusi pendidikan untuk melakukan pembinaan terhadap petani kelapa sawit rakyat.

\section{UCAPAN TERIMA KASIH}

Peneliti mengucapkan terima kasih kepada Lembaga Penelitian dan Pengabdian kepada Masyarakat Universitas Lampung atas bantuan dana Hibah Pascasarjana Unila tahun 2017.

\section{DAFTAR PUSTAKA}

Alatas, A. (2015). Trend Produksi dan Ekspor Minyak Sawit (CPO) Indonesia. AGRARIS: Journal of Agribusiness and Rural Development Research, 1(2), 114-124. http://doi.org/10.18196/agr.1215

Alfin Mohamad, M. A., Hadi Darwanto, D., \& Hartono, S. (2014). Analisis Biaya Transaksi Jagung Hibrida Di Provinsi Gorontalo. SEPA, 11(1), 4954. Retrieved from http://agribisnis.fp.uns.ac.id/wpcontent/uploads/2016/12/05-ANALISIS-BIAYATRANSAKSI-JAGUNG-HIBRIDA.pdf

Dinas Perkebunan Provinsi Lampung, D. P. P. L. (2016). Statistik Perkebunan Tahun 2015. Bandar Lampung: Dinas Perkebunan Provinsi Lampung.

Handley, S. M., \& Benton, W. C. (2012). The influence of exchange hazards and power on opportunism in outsourcing relationships. Journal of Operations Management, 30(1-2), 55-68.

http://doi.org/10.1016/j.jom.2011.06.001

Hartoyo, \& Aniri, N. B. (2010). Analisis tingkat kesejahteraan keluarga pembudidaya ikan dan nonpembudidaya ikan di kabupaten bogor. Jurnal IImu Keluarga Dan Konsumen, 3(1), 6473. Retrieved from http://journal.ipb.ac.id/index.php/jikk/article/vie w/5185/3579

Huo, B., Ye, Y., Zhao, X., Wei, J., \& Hua, Z. (2018). Environmental uncertainty, specific asset, and opportunism in 3PL relationships: A transaction cost economics perspective. International Journal of Production Economics. http://doi.org/10.1016/j.ijpe.2018.01.031

Kissell, R. (2008). Transaction Cost Analysis. The Journal of Trading, 3(2), 29-37. http://doi.org/10.3905/jot.2008.705630

Kusnadi, H. (2005). Ekonomi koperasi: untuk Perguruan Tinggi (Edisi Kedu). Jakarta: Lembaga Penerbit Fakultas Ekonomi Universitas Indonesia.

Lee, P. K. C., Yeung, A. C. L., \& Edwin Cheng, T. C. (2009). Supplier alliances and environmental uncertainty: An empirical study. International
Journal of Production Economics, 120(1), 190 204. http://doi.org/10.1016/.i.jpe.2008.07.019

Lestari, E. E., Hutabarat, S., \& Dewi, N. (2015). Studi Komparatif Perkebunan Kelapa Sawit Rakyat Pola Plasma dan Pola Swadaya Dalam Menghadapi Sertifikasi Rspo (Studi Kasus Desa Bukit Lembah Subur Kabupaten Pelalawan Provinsi Riau). Jurnal Sorot, 10(1), 81-98. http://doi.org/10.1002/ijpg.272

Muslih, A. M., Zakaria, W. A., \& Kasymir, E. (2013). Faktor-faktor yang Mempengaruhi Ekspor CPO Provinsi Lampung. Jurnal IImu-IImu Agribisnis, 1(2), 92-97. http://doi.org/http://dx.doi.org/10.23960/jiia.v $1 \mathrm{i} 2 . \% 25 \mathrm{p}$

Panggabean, S. M., \& Purwono. (2017). Manajemen Pemupukan Tanaman Kelapa Sawit (Elaeis Guineensis Jacq.) Di Pelantaran Agro Estate, Kalimantan Tengah Management of oil palm fertilization in Pelantaran Agro Estate, Center Kalimantan. Buletin Agrohorti, 5(3), 316-324. Retrieved from http://journal.ipb.ac.id/index. php/bulagron/arti cle/viewFile/16469/12086

Samudera, J., \& Daryanto, H. K. (2012). Daya Saing dan Strategi Pengembangan Minyak Sawit di Indonesia. Jurnal Manajemen \& Agribisnis, 9(3), 194-201.

Sari, A. N., Affandi, M. I., \& Abidin, Z. (2014). Analisis Keterkaitan dan Pengganda Perkebunan dan Agroindustri Kelapa Sawit Terhadap Perekonomian Wilayah Provinsi Lampung Jurnal Sosio Ekonomika, 18(2), 95-104.

Siradjuddin, I. (2015). Dampak Perkebunan Kelapa Sawit terhadap Perekonomian Wilayah di Kabupaten Rokan Hulu. Jurnal Agroteknologi, Fakultas Pertanian Dan Peternakan, 5(2), 7-14.

Sultan, H., \& Rachmina, D. (2016). Keuntungan Usahatani Kedelai Di Kabupaten Lamongan, Jawa Timur. Forum Agribisnis, 6(2), 161-178. Retrieved from http://journal.ipb.ac.id/index.php/fagb/article/ view/ 17242

Suratiyah, K. (2015). IImu Usahatani: Edisi Revisi. (S. R. Annisa, Ed.) (1st ed.). Jakarta: Penebar Swadaya.

Syahza, A. (2013). Percepatan Ekonomi Pedesaan melalui Pembangunan Perkebunan Kelapa Sawit. Jurnal Ekonomi Pembangunan, 12(2), 297-310. http://doi.org/10.23917/jep.v12i2.200

Wang, Q., Li, J. J., Ross, W. T., \& Craighead, C. W. (2013). The interplay of drivers and deterrents of opportunism in buyer-supplier relationships. Journal of the Academy of Marketing Science, 41(1), 111-131. http://doi.org/10.1007/s11747-012-0310-9. 